\title{
ANALISIS PENGARUH KUALITAS PRODUK DAN KUALITAS LAYANAN TERHADAP KEPUTUSAN PEMBELIAN PADA AMANDA BROWNIES CABANG SIDOARJO
}

\author{
Nawari \\ Universitas Islam Darul 'Ulum Lamongan \\ e-mail: paknaw11@gmail.com
}

\begin{abstract}
This research was conducted in a company engaged of snack foods amanda brownies branch sidoarjo. The purpose of this study to determine the effect of product quality and service quality on purchase decisions and to determine the most dominant influence of independent variables on the dependent variable. From the results of multiple regression analysis can be taken the regression equation as follows: $\boldsymbol{Y}=$ $15,041+0,483 X 1+0,369 X 2$ Based on the magnitude of the coefficient of determination $\left(\boldsymbol{R}^{2}\right)$ is known that the variable contribution of product quality and service quality on the purchase decision is 0.309 or $31 \%$ Based on the results of the calculation simultaneously or the test $F$ shows $F$ count $=(21.704)>$ Ftable (3.09) and the result of signification is 0,000<0,05, so the independent variable has a significant influence on the dependent variable. While the partial calculation or t test shows the significance of 0.000 and $t$ arithmetic 4,514 means that the quality of the product influence the purchase decision with the significance of 0,000<0.05 and $t$ count (4.541)> t table (0.677). And the result of t test shows sig. 0.000 and t count 2,931 mean that service quality influence on purchasing decision with signification equal to 0,000 $<0,05$ and $t$ count $(2,931)>t$ table $(0,677)$. So, it can be concluded that the product quality is the most dominant influence on purchasing decisions with a $t$ value of 4.541 .
\end{abstract}

Keywords: product quality, service quality, purchase decision

\begin{abstract}
ABSTRAK
Penelitian dilakukan di perusahaan makanan ringan amanda brownies cabang sidoarjo. Tujuan dari penelitian ini adalah untuk mengetahui pengaruh kualitas produk dan kualitas layanan terhadap keputusan pembelian serta untuk mengetahui pengaruh yang paling dominan dari variabel bebas terhadap variabel terikat. Dari hasil analisis regresi berganda diambil persamaan regresinya sebagai berikut: $Y=\mathbf{1 5 , 0 4 1}+\mathbf{0 , 4 8 3} X 1$ + 0,369 X2 Berdasarkan besarnya koefisien determinasi $\left(\boldsymbol{R}^{2}\right)$ diketahui bahwa, besaran kontribusi variabel kualitas produk dan kualitas layanan terhadap keputusan pembelian adalah sebesar 0,309 atau $31 \%$. Berdasarkan hasil perhitungan secara simultan atau uji $\mathrm{f}$ menunjukkan $\mathrm{F}$ hitung $=(21.704)>\mathrm{F}$ tabel $(3,09)$ dan hasil signifikasinya adalah 0,000 $<0,05$, jadi variabel bebas mempunyai pengaruh yang signifikan terhadap variabel terikat. Sedangkan pada perhitungan secara parsial atau uji t menunjukan signifikasi 0,000 dan t hitung 4,514 yang berarti Kualitas produk berpengaruh terhadap keputusan pembelian dengan signifikasi sebesar $0,000<0,05$ dan $t$ hitung $(4.514)>t$ tabel $(0,677)$. Dan hasil dari uji t menunjukan sig. 0,000 dan $\mathrm{t}$ hitung 2.931 yang berarti kualitas layanan berpengaruh terhadap keputusan pembelian dengan signifikasi sebesar $0,000<$ 0,05 dan $\mathrm{t}$ hitung $(2.931)>\mathrm{t}$ tabel $(0,677)$. Maka dapat ditarik kesimpulan bahwa kualitas produk yang paling dominan pengaruhnya terhadap keputusan pembelian dengan nilai t hitung sebesar 4.514.
\end{abstract}

Kata kunci: kualitas produk, kualitas layanan, keputusan pembelian 


\section{PENDAHULUAN}

Pada dekade ini perkembangan dunia semakin maju dan perkembangan keilmuan juga semakin berkembang dari berbagai segi kehidupan mulai dari disiplin ilmu, teknologi, politik, hukum, ekonomi dan juga bisnis. Dari bebagai bebagai perkembangan yang sudah disebutkan diatas dari segi ekonomi dan bisnis yang paling cepat perkembangannya, hal ini tidak mengejutkan karena seiring dengan kemajuan manusianya juga harus disertai kemajuan dalam hal ekonomi dan bisnis.

Penelitian ini akan meneliti suatu produk brownies yang ada di sidiorjo, melihat persaingan produksi kue di indonesia akhir-akhir ini begitu semarak dengan hadirnya produk-produk baru yang hadir dari dunia hiburan negeri ini, produk mereka pasti mendapatkan beberapa keuntungan tersendiri, mengingat mereka merupakan publik figur di indosesia secara otomatis mereka akan lebih mudah mengenalakan produknya terhadap halayak terutama pengemar mereka, dari deretan artis tanah air yang merambah dunia bisnis antara lain, irwansyah yang membuat produk napoleon medan, zaskia sungkar dengan produk snowcake surabaya, shireen sungkar dengan raincake bogor, teuku wisnu dengan produk strudel malang, laudya chintya bella dengan produk makuta bandung, dude herlino dengan produk scrummy jogja, glenn alinskie dengan produk lamington ponteanak dan masih banyak lagi artis yang membuat produk baru yang masing-masing mempunyai karasteristik yang berbeda-beda, hal ini dilakukan untuk menarik minat konsumen untuk mempebeli prodak yang mereka miliki, selain meningkatkan kualitas produk, terdapat faktor lain yang juga mempengaruhi keputusan konsumen untuk mengkonsumsi suatu produk yaitu, kualitas layanan, yang mana kualitas layanan ini juga memegang peranan penting dalam suatu usaha, mengingat kualitas layanan yang diterapkan oleh beberapa toko-toko atau minimarket-minimarket, yang sudah familiar kualitas layanannya, berdasar latar belakang diatas peneliti berniat untuk meneliti pengaruh kualitas produk dan kualitas layanan terhadap keputusan pembelian di amanda brownies cabang sidoarjo.

\section{Rumusan masalah}

1. Adakah pengaruh kualitas produk dan kualitas layanan terhadap keputusan pembelian pada konsumen Amanda Brownies Sidoarjo? 
2. Seberapa besar kontribusi pengaruh masing-masing variabel bebas kualitas produk dan kualitas layanan terhadap variabel terikat keputusan pembelian pada konsumen Amanda Brownies Sidoarjo?

\section{TINJAUAN PUSTAKA}

\section{Kualias produk}

Menurut Kotler dan Keller (2011:143) kualitas produk adalah kemampuan suatu barang untuk memberikan hasil atau kinerja yang sesuai bahkan melebihi dari apa yang diinginkan pelanggan. Sedangkan menurut Kotler dan Amstrong (2011:299) kualitas produk adalah kemampuan produk untuk menampilkan fungsinya, hal ini termasuk waktu dan kegunaan dari produk, keandalan dalam penggunaan dan perbaikan dan nilainilai yang lainnya. Pada hakekatnya seseorang membeli suatu produk bukan hanya sekedar ingin memiliki produk tersebut, akan tetapi para konsumen tersebut juga dapat menggunakan produk tersebut sebagai alat untuk memuaskan kebutuhan dan keinginannya sehingga tidak hanya untuk fisik saja yang diperhatikan melainkan juga bagaimana suatu produk dapat memberi manfaat dari apa yang bisa di timbulkan oleh produk tersebut.

Pada dasarnya produk yang dibeli oleh para konsumen dapat dibedakana sebagai berikut:

1) Produk inti, yang merupakan inti atau dasar sesungguhnya dari produk yang ingin diperoleh atau didapatkan oleh seorang pembeli.

2) Produk formal, yang merupakan bentuk, model, kualitas, merek dan kemasan yang menyertai produk tersebut.

3) Produk tambahan, adalah tambahan produk formal dengan berbagai jasa yang menyertainya, seperti pemasangan, instalasi pelayanan, pemeliharaan dan pengangkutan secara cuma-cuma.

\section{Kualitas layanan}

Kualitas layanan menjadi suatu keharusan yang harus dilakukan perusahaan supaya mampu bertahan dan tetap mendapat kepercayaan pelanggan. Pola konsumsi dan gaya hidup pelanggan menuntut perusahaan mampu memberikan pelayanan yang berkualitas. Keberhasilan perusahaan dalam memberikan pelayanan yang berkualitas 
dapat ditentukan dengan pendekatan service quality yang telah dikembangkan oleh Parasuraman, Berry dan Zenthaml dalam Hardiyanti ( 2010: 09).

Menurut Tjiptono (2006:70) dimensi kualitas pelayanan terdiri dari beberapa bagian antara lain sebagai berikut:

1) Responsiveness yang merupakan keinginan para staf untuk membantu para konsumen dan memberikan layanan dengan tanggap. Responsiveness dapat berarti tingkat respon, inisiatif, dan kesigapan karyawan dalam membantu pelanggan dan memberikan layanan yang cepat, yang meliputi kecepatan karyawan dalam menangani transaksi dan kesigapan serta kesabaran penanganan dalam proses konsumsi jasa. Para anggota perusahaan harus memperhatikan janji spesifik kepada pelanggan.

2) Reliability yang merupakan kemampuan memberikan layanan yang dijanjikan dengan segera, akurat dan memuaskan. Hal ini berarti perusahaan memberikan jasanya secara tepat semenjak saat pertama. Selain itu juga berarti bahwa perusahaan yang bersangkutan memenuhi janjinya, misalnya: menyampaikan jasanya sesuai dengan jadwal yang disepakati.

3) Assurance yang merupakan pengetahuan, kemampuan, kesopanan, dan sifat dapat dipercaya yang dimiliki para staf; bebas dari bahaya, risiko atau keragu-raguan.

4) Empathy yang merupakan kemudahan dalam melakukan hubungan, komunikasi yang baik, perhatian pribadi, dan memahami kebutuhan para konsumen., mengerti kemauan dan kebutuhan pelanggan dapat di aktualisasikan.

5) Tangible yang meliputi fasilitas fisik, perlengkapan, pegawai, dan sarana komunikasi. Hal ini bisa berarti penampilan fasilitas fisik, seperti gedung dan ruangan, tersedianya tempat parkir, keberhasilan, kerapian dan kenyamanan ruangan, kelengkapan peralatan komunikasi, dan penampilan karyawan.

\section{Keputusan pembelian}

Menurut Kotler dan Keller (2008:181), keputusan pembelian konsumen adalah membeli merek yang paling disukai dari berbagai alternatif yang ada, tetapi dua faktor berada antara niat pembelian dan keputusan pembelian. Menurut Kotler dan Amstrong (2008:181), proses pengambilan keputusan merupakan perilaku yang harus dilakukan untuk dapat mencapai sasaran, dan dengan demikian dapat memecahkan masalahnya. Dijelaskan pada proses keputusan pembelian sebagai berikut:

1) Pengenalan kebutuhan

2) Pencari informasi

3) Evaluasi alternatif 
4) Keputusan pembelian

5) Prilaku setelah pembelian

\section{Kerangka konseptual}

\section{Gambar 1 Kerangka Konsep Penelitian}

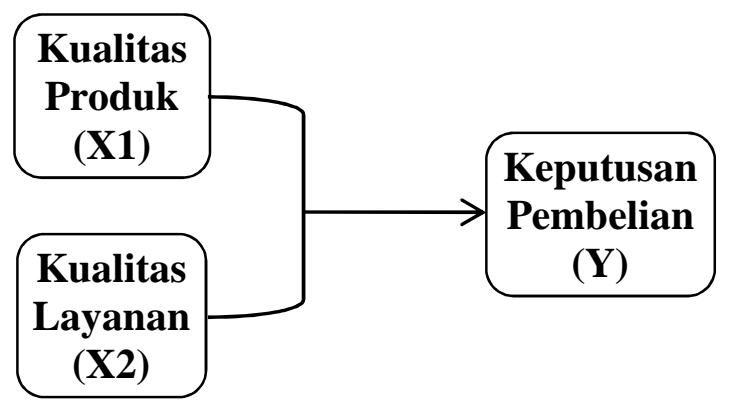

\section{Hipotesis penelitian}

1. H1 Diduga terdapat pengaruh positif secara parsial antara kualitas produk terhadap keputusan pembelian

2. H2 Diduga terdapat pengaruh positif secara parsial antara kualitas layanan terhadap keputusan pembelian.

3. H3 Diduga terdapat pengaruh positif secara simultan antara lokasi, kualitas produk dan kualitas layanan terhadap keputusan pembelian.

\section{METODE PENELITIAN}

\section{Populasi dan sampel}

Populasi menurut Arikunto (2013:173) adalah keseluruhan sujek penelitian. Apa bila seseorang ingi meneliti semua elemen yang ada dalam wilayah penelitian maka penilitiannya merupakan penelitian populasi. Sedangkan menurut Sugiono (2015:215) wilayah generalisasi yang terdiri atas: objek/subjek yang mempunyai kualitas dan karakteristik tertentu yang ditetapkan oleh peneliti untuk dipelajari dan kemudian ditarik kesimpulannya. Populasi dalam penelitian ini adalah semua konsumen baik secara individu atau kelompok yang membeli Amanda Brownies cabang sidoarjo

Sampel adalah sebagian atau wakil populasi yang diteliti Arikunto (2013:173). Sampel adalah bagian dari jumlah dan karakteristik yang dimiliki oleh populasi tersebut. Sampel terdiri atas sejumlah anggota yang dipilih dari populasi Sugiono (2015:215). 
Dalam penelitian ini peneliti mengambil sampel sebanyak 100 responden dari pembeli di Amanda Brownies cabang sidoarjo dari bulan Juni sampai dengan bulan juli dengan menggunakan teknik simple random sampling dimana pengambilan sampel dari populasi dilakukan secara acak tampa memperhatikan strata yang ada dalam populasi tersebut.

\section{Identifikasi variabel}

Pengertian variabel menurut Sugiaono, (2015:38) adalah segala yang berbentuk apa saja yang ditetapkan oleh peneliti untuk dipelajari sehingga diperoleh informasi tentang hal tersebut, kemudian ditarik kesimpulannya. Dalam penelitian ini variabel yang akan diteliti adalah sebagai berikut:

1. Variabel independen

Variabel independen atau variabel bebas adalah merupakan variabel yang mempengaruhi atau yang menjadi sebab perubahannya atau timbulnya variabel dependen. Sedangkan dalam penelitian ini, peneliti menggunakan 2 (dua) variabel independen atau bebas yaitu, Kualitas produk (X1) dan Kualitas layanan (X2).

2. Variabel dependen

Variabel dependen atau terikat adalah merupakan variabel yang dipengaruhi atau yang menjadi akibat, karena adanya variabel bebas. Sedangkan dalam penelitian ini variavel dependenya adalah Keputusan pembelian (Y).

\section{Teknik Pengumpulan data}

Pengumpulan data merupakan prosedur yang sistematis dan standar untuk memperoleh data yang diperlukan. Selalu ada hubungan antara metode mengumpulkan data dengan masalah penelitian yang ingin dipecahkan. Masalah memberi arah dan mempengaruhi metode pengumpulan data. Banyak masalah yang dirumuskan tidak akan bisa terpecahkan karena metode untuk memperoleh data yang diinginkan tidak memungkinkan ataupun metode yang ada tidak dapat menghasilkan data seperti yang diinginkan. ( Nazir, Moh. 2014:153).

Pengumpulan data dapat dilakukan dalam berbagai setting, berbagai sumber, dan berbagai cara. bila dilihat dari setting nya data dapat dikumpulkan pada setting alamiah ( natural setting), pada laboratorium dengan metode eksperimen, dirumah dengan berbagai responden, pada suatu seminar, diskusi, dijalan dan lain-lain. Bila dilihat dari 
sumber datanya maka pengumpulan data menggunakan sumber-sumber primer dan sumber-sumber sekuander. (Sugiyono.2015:137).

Tehnik pengumpulan data dapat dilakukan dengan beberapa cara antara lain interview (wawancara), kuesioner (angket), observasi (pengamatan), dan gabungan ketiganya. Dalam penelitian ini, peneliti menggunakan kuesioner atau angket dengan cara memberi seperangkat pertanyaaan atau pernyataan tertulis kepada responden untuk dijawab dan selanjutnya dianalisis dan diambil kesimpulannya.

\section{Skala Linkert}

Skala linkert digunakan untuk mengukur sikap, pendapat dan persepsi sesorang atau sekelompok orang tentang fenomena sosial. Dalam penelitian fenomena sosial ini telah ditetapkan secara spesifik oleh peneliti yang selanjutnya disebut sebagai variabel penelitian. Dalam penelitian ini menggunakan variabel X1, X2 dan Y yang kemudian variabel tersebut dijadikan sebagai titik tolak untuk menyususn item-item instrumen yang dapat berupa pernyataan atau pertanyaan, jawaban setiap item instrumen yang menggunakan skala linkert mempunyai gradasi dari sangat positif sampai sangat negatif, seperti berikut:
a. Sangat Setuju
b. Setuju
c. Ragu-ragu
d. Tidak setuju
e. Sangat tidak setuju

\section{Tekni Analisis Data}

Dalam penelitian kuantitatif, teknik analisis data yang digunakan judah jelas, yaitu diarahkan untuk menjawab rumusan masalah atau menguji hipotesis yang telah dirumuskan sebelumnya, karena datanya kuantitatif, maka teknik analisis data menggunakan statistik yang sudah tersedia.

\section{Uji Validitas}

Uji validitas digunakan untuk mengukur sah atau valid tidaknya suatu kuesioner. Suatu kuesioner dikatakan valid apabila pertanyaan pada kuesioner mampu mengungkapkan sesuatu yang akan diukur oleh kuesioner tersebut.jadi validitas adalah mengukur apakah pertanyaan dalam kuesioner yang sudah dibuat betul-betul bisa mengukur apa yang hendak diukur. Dalam penelitian ini peneliti menggunakan program SPSS versi 22 
untuk menguji validitas kuesioner dengan membandingkan antara nilai $r$ hitung dan $r$ tabel dengan rumus tabel $\mathrm{df}=\mathrm{n}-2$, dan $\alpha=>0,05$, maka data kuesioner dikatakan valid apabila $\mathrm{r}$ hitung $>\mathrm{r}$ tabel dan sig $>0,05$

\section{Uji reliabilitas}

Uji reliabilitas adalah alat untuk mengukur suatu kuesioner yang merupakan indikator dari variabel atau konstruk. Suatu kuesioner dikatakan handal apabila jawaban responden terhadap pernyataan konsisten atau stabil dari waktu ke waktu. Jawaban responden terhadap pertanyaan dikatakan reliabel apabila masing-masing pertanyaan dijawab secara konsisten atau jawab tidak boleh diacak oleh karena masing masing pertanyaan hendak mengukur yang sama. Pengukuran reliabilitas dapat dilakukan dengan menggunakan program SPSS. Suatu data kuesioner dikatakan reliabel apabila hasil Alpha Cronbach >0,06.

\section{Analisis Korelasi}

Korelasi adalah hubungan antara dua variabel secara linier. Nilai korelasi terletak pada -1 dan +1 , nilai korelasi mendekati -1 artinya bahwa ada hubungan antara dua variabel dan jenis hubungan tersebut adalah berbanding terbalik. Nilai korelasi mendekati 0 artinya tidak ada korelasi antara dua variabel sedangkan jika nilai korelasi mendekati angaka 1 artinya terdapat hubungan yang saling tegak lurus antara dua variabel. Analisis korelasi digunakan untuk mengetahui hubungan antara dua variabel (bivariate correlation) atau lebih dari dua variabel (multi bivariate correlation).

\section{Analisis Regresi Berganda}

Setelan melalui proses analisis korelasi kedua variabel independen terhadap variabel dependen selanjutnya yang dilakukan adalah analisis regresi, analisis regresi digunakan untuk melihat hubungan antara variabel bebas dengan variabel terikatnya, hubungan tersebut terjadi dalam bentuk persamaan.

\section{Uji hipotesis}

Uji hipotesis merupaka suatu teknik statistik yang digunakan untuk mengetahui apakan variabel bebas secara parsial berpengaruh terhadap variabel terikat signifikan atau tidak. Adapun level signifikan $(\alpha)$ sebesar 5\%. Keriteria pengambilan keputusannya adalah (a) jika nilai signifikan sig $\leq 0,05$ maka variabel bebas berpengaruh terhadap variabel terikat (a) jika nilai signifikan sig $\geq 0,05$ maka variabel bebas tidak berpengaruh terhadap variabel terikat. 


\section{HASIL \& PEMBAHASAN}

\section{Tabel 1 Hasil uji validitas}

Comelations

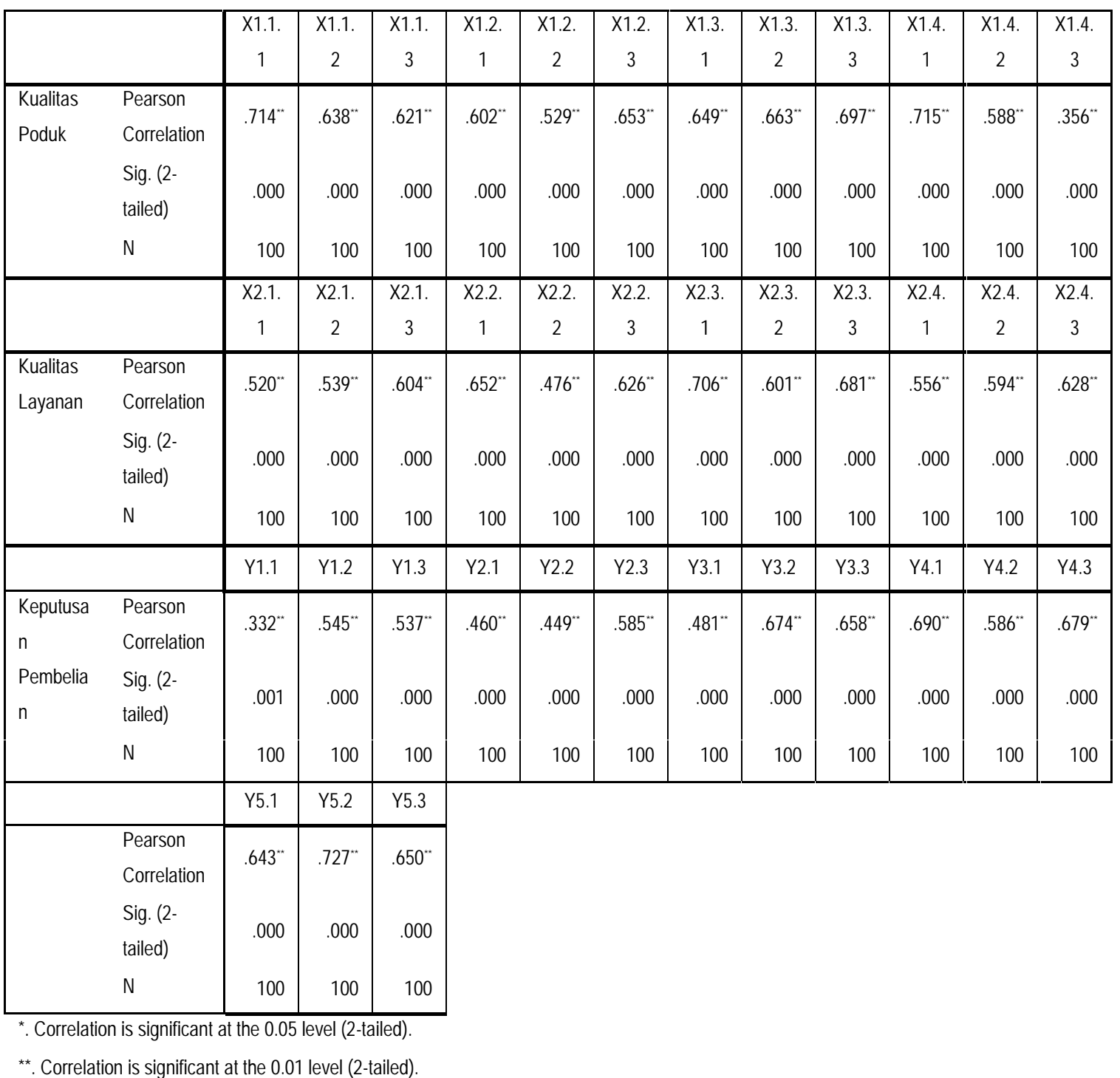

Berdasarkan tabel hasil uji validitas di atas maka diketahui untuk uji validitas adalah seluruh item pertanyaan yang ada pada setiap variabel dinyatakan valid karena angka signifikasinya lebih kecil dan 0,05 dan pearson correaltion bernilai positif (+) dan bernilai lebih besar dari 0,197 ( $\mathrm{r}$ tabel) dengan $\mathrm{df}=\mathrm{n}-2$ atau $\mathrm{df}=98$. 
Tabel 2 Hasil uji relibialitas

Reliability Statistics Kualitas Produk

\begin{tabular}{|r|r|}
\hline Cronbach's Alpha & N of Items \\
\hline .848 & 12 \\
\hline Reliability Statistics Kualitas Layanan \\
\hline Cronbach's Alpha & N of Items \\
\hline .835 & 12 \\
\hline Reliability Statistics Keputusan Pembelian \\
\hline Cronbach's Alpha & N of Items \\
\hline .860 & \\
\hline
\end{tabular}

Uji realibilitas dapat dikatakan reliabel apa bila nilai Cronbach's Alpha lebih besar dari 0,06. Dari hasil uji reliabilitas yang tertera pada variabel kualitas produk (X1) dinyatakan reliabel karna hasil Cronbach's Alpha 0,848 > 0,06. Pada variabel kualitas layanan (X2) dinyatakan reliabel karna hasil Cronbach's Alpha 0,835 > 0,06. Dan pada variabel keputusan pembelian (Y) dinyatakan reliabel karna hasil Cronbach's Alpha $0,860>0,06$.

Tabel 3 Hasil uji korelasi

Correlations

\begin{tabular}{|ll|r|r|r|}
\hline & \multicolumn{1}{|c|}{$\begin{array}{c}\text { Kualitas } \\
\text { Poduk }\end{array}$} & $\begin{array}{c}\text { Kualias } \\
\text { Layanan }\end{array}$ & \multicolumn{1}{c|}{$\begin{array}{c}\text { Keputusan } \\
\text { Pembelian }\end{array}$} \\
\hline Kualitas Poduk & Pearson Correlation & 1 & $.348^{* *}$ & $.498^{* *}$ \\
& Sig. (2-tailed) & .000 & .000 \\
& $\mathrm{~N}$ & 100 & 100 & 100 \\
\hline Kualitas Layanan & Pearson Correlation & $.348^{* *}$ & 1 & $.405^{* *}$ \\
& Sig. (2-tailed) & .000 & .000 \\
& $\mathrm{~N}$ & 100 & 100 & 100 \\
\hline Keputusan Pembelian & Pearson Correlation & $.498^{* *}$ & $.405^{* *}$ & 1 \\
& Sig. (2-tailed) & .000 & .000 & 100 \\
\hline
\end{tabular}

${ }^{\star *}$. Correlation is significant at the 0.01 level (2-tailed).

Hasil analisis korelasi dapat dikatakan ada hubungan apa bila nilai sig. (2-tailed) lebih kecil dari 0,000 dan tidak signifikan jika nilai sig. (2-tailed) lebih besar dari 0,01. Dari hasil perhitungan analisis korelasi dapat diketahui bahwa terdapat hubungan antara variabel kualitas produk dan kualitas layanan sebesar 0,348 dengan tanda dua bintang 
yang menunjukan bahwa tedapat hubungan yang kuat antara variabel kualitas produk dengan kualitas layanan. Pada sig. (2-tailed) sebesar 0,000 dengan menggunakan signifikasi 0,01. Dikatakan signifikan apabila nilai sig. (2-tailed) lebih kecil dari 0,01. Hubungan yang terdapat pada kualitas produk terhadap keputusan pembelian sebesar 0,498 dengan tanda dua bintang yang menunjukan bahwa tedapat hubungan yang kuat antara variabel kualitas produk dengan keputusan pembelian. Pada sig. (2-tailed) sebesar 0,000 dengan menggunakan signifikasi 0,01. Sedangkan hubungan yang terdapat pada kualitas layanan terhadap keputusan pembelian sebesar 0,405 dengan tanda dua bintang yang menunjukan bahwa tedapat hubungan yang kuat antara variabel kualitas produk dengan keputusan pembelian. Pada sig. (2-tailed) sebesar 0,000 dengan menggunakan signifikasi 0,01. Dari hasil analisis di atas maka dapat disimpulkan bahawa ada hubungan yang signifikan dari semua variabel yang terdapat pada penelitian ini.

\section{Analisis regresi berganda}

Analisis regresi digunakan untuk mengetahui apakah ada pengaruh variabel kualitas produk dan kualitas layanan terhadapa variabel keputusan pembelian. Hasil analisis dengan persamaan regresinya adalah sebagai berikut:

$$
Y=a+\beta_{1} X_{1}+\beta_{2} X_{2}
$$

Berdasarkan persamaan regresi di atas, maka untuk mengetahui sejauh mana pengaruh kualitas produk dan kualitas layanan terhadap keputusan pembelian konsumen adalah sebagai berikut:

\section{Tabel 4 Koefisien}

Coefficients $^{\text {a }}$

\begin{tabular}{|c|c|c|c|c|c|c|}
\hline \multirow{2}{*}{\multicolumn{2}{|c|}{ Model }} & \multicolumn{2}{|c|}{ Unstandardized Coefficients } & \multirow{2}{*}{$\begin{array}{c}\text { Standardized } \\
\text { Coefficients } \\
\text { Beta }\end{array}$} & \multirow[b]{2}{*}{$\mathrm{t}$} & \multirow[b]{2}{*}{ Sig. } \\
\hline & & $\mathrm{B}$ & Std. Error & & & \\
\hline \multirow[t]{3}{*}{1} & (Constant) & 15.041 & 5.330 & & 2.822 & .006 \\
\hline & Kualitas Poduk & .483 & .107 & .406 & 4.514 & .000 \\
\hline & Kualias Layanan & .369 & .126 & .264 & 2.931 & .004 \\
\hline
\end{tabular}

a. Dependent Variable: Keputusan Pembelian 
Berdasarkan tabel Coefficients hasil analisis berganda pada kolom Unstandardized Coefficients persamaan kualitas produk dan kualitas layanan terhadap keputusan pembelian konsumen adalah sebagai bertikut:

$Y=15,041+0,483 X_{1}+0,369 X_{2}$

Persamaan regresi di atas menunjukan hasil pada saat nilai kualitas produk (X1) dan kualitas layanan (X2) bernilai 0 (nol) yang berarti konstan, maka nilai keputusan pembelian (Y) sebesar 15,041. Setiap ada kenaikan variabel bebas kualitas produk (X1) dan kualitas layanan (X2) sebesar satuan, maka akan meningkat variabel terikatnya keputusan pembelian (Y) sebesar nilai koefesien beta masing-masing variabel bebas dikalikan dengan besarnya kenaikan yang terjadi. Hal ini berarti semakin tepat pemenuhan kualitas produk dan kualitas layanan maka semakin mampu mempengaruhi keputusan pembelian.

\section{Hasil uji hipotesis}

Untuk menguji kesesuaian model persamaan regresi yang dihasilkan dan untuk menguji signifikasi dan tidaknya variabel kualitas produk (X1) dan kualitas layanan (X2) terhadap variabel keputusan pembelian (Y) analisisnya menggunakan uji t dan uji f.

a. Uji f

\section{Tabel 5 Uji f}

ANOVA ${ }^{\mathrm{a}}$

\begin{tabular}{|rr|r|r|r|r|r|}
\hline Model & & Sum of Squares & Df & Mean Square & \multicolumn{1}{c|}{ F } & \multicolumn{1}{c|}{ Sig. } \\
\hline 1 & Regression & 1808.621 & 2 & 904.310 & 21.704 & $.000^{\mathrm{b}}$ \\
& Residual & 4041.489 & 97 & 41.665 & & \\
& & 5850.110 & 99 & & & \\
& Total & & & & \\
\hline
\end{tabular}

a. Dependent Variable: Keputusan Pembelian

b. Predictors: (Constant), Kualias Layanan, Kualitas Poduk

Dari hasil perhitungan dengan menggunakan aplikasi SPSS yang telah tersaji pada tabel di atas dapat diketahui bahwa hasil Fhitung sebesar 21.704. jika Fhitung $>$ Ftabel maka hasil perhitungan signifikan. Dan jika Fhitung $<F_{\text {tabel }}$ maka hasil perhitungan tidak signifikan. pada level signifikan 95\% $\alpha=0,05$. Pada penelitian ini variabel bebas kualitas produk (X1) dan kualitas layanan (X2) berpengaruh terhadap variabel terikat keputusan pembelian $(\mathrm{Y})$ dengan hasil yang menunjukkan Fhitung $=(21.704)>F_{\text {tabel }}$ $(3,09)$ dengan sig. $0,000<0,05$. 
b. Uji t

\section{Tabel 6 Uji t}

Coefficients $^{\mathrm{a}}$

\begin{tabular}{|c|c|c|c|c|c|c|}
\hline \multirow{2}{*}{\multicolumn{2}{|c|}{ Model }} & \multicolumn{2}{|c|}{ Unstandardized Coefficients } & \multirow{2}{*}{$\begin{array}{c}\begin{array}{c}\text { Standardized } \\
\text { Coefficients }\end{array} \\
\text { Beta }\end{array}$} & \multirow[b]{2}{*}{$\mathrm{t}$} & \multirow[b]{2}{*}{ Sig. } \\
\hline & & $B$ & Std. Error & & & \\
\hline \multirow[t]{3}{*}{1} & (Constant) & 15.041 & 5.330 & & 2.822 & .006 \\
\hline & Kualitas Poduk & .483 & .107 & .406 & 4.514 & .000 \\
\hline & Kualitas Layanan & .369 & .126 & .264 & 2.931 & .004 \\
\hline
\end{tabular}

a. Dependent Variable: KeputusanPembelian

Dalam uji t suatu variabel kualitas produk (X1) atau kualitas layanan (X2) dapat dikatakan berpengaruh secara parsial terhadap variabel keputusan pembelian (Y) apabila nilai sig. $<0,05$, dan $t$ hitung $>\mathrm{t}$ tabel, dan variabel kualitas produk (X1) atau kualitas layanan (X2) dapat dikatakan tidak berpengaruh secara parsial terhadap variabel keputusan pembelian (Y) apabila nilai sig. > 0,05, dan t hitung < t tabel. Dari hasil outpu diatas adalah sebagai berikut:

1. Hasil dari uji t menunjukan sig. 0,000 dan t hitung 4,514 yang berarti Kualitas produk (X1) berpengaruh terhadap keputusan pembelian (Y) dengan sig. 0,000 < 0,05 dan $t$ hitung $(4.514)>t$ tabel $(0,677)$.

2. Hasil dari uji $\mathrm{t}$ menunjukan sig. 0,000 dan $\mathrm{t}$ hitung 2.931 yang berarti kualitas layanan (X2) berpengaruh terhadap keputusan pembelian (Y) dengan sig. 0,000< 0,05 dan $\mathrm{t}$ hitung $(2.931)>\mathrm{t}$ tabel $(0,677)$.

c. Uji determinasi

Tabel 7 Uji Determinasi

Model Summary

\begin{tabular}{|l|r|r|r|r|}
\hline Model & $\mathrm{R}$ & R Square & $\begin{array}{c}\text { Adjusted R } \\
\text { Square }\end{array}$ & $\begin{array}{c}\text { Std. Error of the } \\
\text { Estimate }\end{array}$ \\
\hline 1 & $.556^{\mathrm{a}}$ & .309 & .295 & 6.45483 \\
\hline
\end{tabular}

Hasil dari analisis determinasi pada tabel Model Summary ${ }^{\mathbf{b}}$ menunjukan bahwa besar pengaruh antara variabel kualitas produk (X1) dan kualitas layanan (X2) terhadap keputusan pembelian (Y) sebesar 0,309 sehingga sumbangan pengaruh variabel X1 dan X2 terhadap Y secara simultan adalah 31\% sedangkan sisanya sebesar 69\% dipengaruhi faktor lain yang tidak termasuk pada penelitian ini. 


\section{KESIMPULAN DAN SARAN}

\section{Simpulan}

Hasil dari analisis dari penelitian ini menunjukan adanya pengaruh kualitas produk dan kualitas layanan terhadap keputusan pembelian pada konsumen Amanda Brownies Sidoarjo dengan pengaruh sebesar 0,309 sehingga sumbangan pengaruh variabel kualitas produk ( X1) dan kualitas layanan (X2) terhadap keputusan pembelian (Y) secara simultan adalah $31 \%$.

Berdasarkan analisis uji t besar kontribusi masing-masing variabel bebas kualitas produk (X1) dan kualitas layanan (X2) terhadap variabel terikat keputusan pembelian (Y) pada konsumen Amanda Brownies Sidoarjo adalah sebagai berikut:

a. Kualitas produk (X1) berpengaruh terhadap keputusan pembelian (Y) dengan sig. $0,000<0,05$ dan $\mathrm{t}$ hitung $(4.541)>\mathrm{t}$ tabel $(0,677)$.

b. Kualitas layanan (X2) berpengaruh terhadap keputusan pembelian (Y) dengan sig. $0,000<0,05$ dan $t$ hitung $(2.931)>t$ tabel $(0,677)$.

\section{Saran}

Berdasarkan pada penelitian yang telah dilakukan serta kesimpulan yang diperoleh dari penelitian ini, maka peneliti berusaha menyumbangkan saran-saran yang mungkin bermanfaat bagi peneliti selanjutnya, adapun saran yang dapat diberikan oleh peneliti di dalam penelitian ini adalah peneliti selanjutnya bisa menggunakan atau menambahkan variabel-variabel lain yang belum dimasukkan dalam penelitian ini, hal ini yang mungkin tidak terabaikannya faktor lain yang lebih fundamintal dan mungkin justru memberikan pengaruh yang lebih besar dalam pengambilan keputusan pembelian konsumen.

\section{DAFTAR PUSTAKA}

Arikunto suharsimi. (2013). Prosedur Penelitian Suatu Pendekatan Praktis. PT Rinika Cipta. Jakarta

Ghozali imam. (2005) Aplikasi Analisi Multivariate Dengan Program SPSS, Universitas Diponegoro. Semarang

Hardiyanti Ratih, 2010. Analisis Pengaruh Kualitas Pelayanan Terhadap Kepuasan Konsumen Menggunakan Jasa Penginapan (Villa) Agrowisata Kebun Teh Pagilaran, Pagilaran, Universitas Diponegoro. Semarang. 
Irianti E. Qomariyah N. dan Suharto A, 2016. Pengaruh kualitas produk dan lokasi terhadap loyalitas pelanggan melalui kepuasan sebagai variabel intervening pada depot mie pangsit jember, jurnal manajemen dan bisnis indonesia vol 2 . no.1hal.4

Kotler, P dan G. Amstrong. 2008 Marketing an introduction. Ninth Edition.New. Prentice Hall. New Jersey

Kotler, P dan C. Keller.2008 Manajemen Pemasaran (edisi ketiga belas). PT. Indeks Jakarta

Kotler, P dan C. Keller. (2011). Marketing Management, edisi ke tiga belas, Erlangga Jakarta

Nasir Moh. (2014). Metode Penelitian cet. kesembilan. Ghalia Indonesia. Bogor

Sugiyono. (2015). Metode Penelitian Kuantitatif Kualitatif dan R\&D, Alfabeta Bandung

Tjiptono, Fandy (2006). Manajemen Jasa. Edisi ke satu, Penerbit Andi, Yogyakarta.

Tjiptono, Fandy (2008). Strategi Pemasaran. Edisi ke dua, Penerbit Andi, Yogyakarta. 